\title{
The status of children's rights in early childhood education policy 2009
}

\section{Sarah Te One AND CARMEn DaLli}

\section{Abstract}

Under the current National-led government the combined effects of a new political agenda and a world-wide recession have resulted in a discernible shift in policy priorities. Using a children's rights-based lens, this paper considers changes in early childhood policy during 2009 and argues that these shifts impact the integrity of the 10-year early childhood Strategic Plan introduced in 2002. They also put in question whether children's rights to high-quality early childhood education policy are really taken seriously within the policy arena. The issue of government's role in providing high quality early childhood services is highlighted as one that derives from children's citizenship rights. The paper concludes that a new critical ecology of the early childhood sector is emerging which uses a children's rights perspective to evaluate current policy and envision possible futures.

\section{Introduction}

Tn her speech to the inaugural Early Childhood Special Interest Group at the 2009 conference of the New Zealand Association for Research in Education, Anne Smith (2009) celebrated the $20^{\text {th }}$ anniversary of the United Nations Convention on the Rights of the Child (UNCRC) ${ }^{1}$ (United Nations, 1990) by highlighting some of the markers for children's rights in the early childhood sector. She pointed to Te Whäriki (Ministry of Education, 1996a), the national early childhood curriculum statement as a taonga (a treasure) which encapsulates aspirations for children that are based on children's rights, including within early childhood education services. On a more sobering note, Smith commented that the 2009 Budget cuts had effectively stalled the momentum towards improving quality services for children and for communities which had built up over recent years. She commented that the world-wide recession has provided the current administration with reasons to tighten public spending, and 
with a rationale to alter, and even cut, existing early childhood education policies.

This paper builds on Smith's (2009) argument. Taking a children's rights perspective we review early childhood education policy decisions made in the name of economic constraints in 2009, including through the 2009 Budget cuts, and argue that the changes have de-stabilised the coherent policy infrastructure of the early childhood strategic plan, Pathways to the future. Ngā Huarahi Arataki (Ministry of Education, 2002). Beginning with an explanation of children's rights as a lens for analysing early childhood education policy, the paper argues that a necessary corollary of acknowledging children's rights is the obligation to set in place policies that support their implementation. We review the status of early childhood education policy in 2009 and conclude by supporting Dalli's (2010) call for the emergence of a new "critical ecology" for the early childhood sector in which children's rights to high-quality professional early childhood services are taken seriously.

\section{Why a children's rights perspective is important}

The UNCRC is one of 12 Human Rights treaties. In the UNCRC, the focus is on the rights of children and concomitant responsibilities of society towards children.

One way to understand the UNCRC has been to group the articles into three categories; the categories are all interrelated and influenced by the contexts in which they are implemented. Recent research (Taylor, Smith, \& Gollop, 2009) conducted across six countries concluded that despite mixed findings, children perceived their rights in similar ways that covered most of the rights in the UNCRC, as illustrated in Table 1. 
Table 1: Categories of rights, accepted definitions and children's perceptions of their rights

\begin{tabular}{|c|c|c|}
\hline $\begin{array}{l}\text { Categories of } \\
\text { children's } \\
\text { rights }\end{array}$ & $\begin{array}{c}\text { Definitions } \\
\text { (Lansdown, 1994, p. 36) }\end{array}$ & $\begin{array}{c}\text { Children's perceptions } \\
\text { (Taylor \& Smith, 2009, } \\
\text { p. 171) }\end{array}$ \\
\hline $\begin{array}{l}\text { Provision } \\
\text { rights }\end{array}$ & $\begin{array}{l}\text { Rights to minimum standards } \\
\text { of family life and access to } \\
\text { parental care, health, } \\
\text { education social security, } \\
\text { physical care, play, recreation, } \\
\text { culture and leisure. }\end{array}$ & $\begin{array}{l}\text { Parental care and nurturance, } \\
\text { education, sustenance (food, } \\
\text { clothing and housing), healthy } \\
\text { environments, recreation/play } \\
\text { opportunities, medical care, } \\
\text { transport, spaces to hang out, } \\
\text { access to employment, access } \\
\text { to resources (e.g., equipment } \\
\text { in schools). }\end{array}$ \\
\hline $\begin{array}{l}\text { Protection } \\
\text { rights }\end{array}$ & $\begin{array}{l}\text { The right to be safe from } \\
\text { discrimination, physical and } \\
\text { sexual abuse, exploitation, } \\
\text { substance abuse, injustice and } \\
\text { conflict. }\end{array}$ & $\begin{array}{l}\text { Protection from bullying by } \\
\text { peers, safety at school, home } \\
\text { and in the community, } \\
\text { freedom from drugs and } \\
\text { alcohol, freedom from } \\
\text { discrimination and racism, } \\
\text { protection from sexual abuse, } \\
\text { violence and forced labour and } \\
\text { to be treated fairly. }\end{array}$ \\
\hline $\begin{array}{l}\text { Participation } \\
\text { rights }\end{array}$ & $\begin{array}{l}\text { Civil and political rights, such } \\
\text { as the right to a name and an } \\
\text { identity, to be consulted and to } \\
\text { be taken into account, to } \\
\text { physical integrity, to } \\
\text { information, to freedom of } \\
\text { speech and opinion and to } \\
\text { challenge decisions made on } \\
\text { their behalf. }\end{array}$ & $\begin{array}{l}\text { To have a say, choose friends, } \\
\text { be respected, express } \\
\text { opinions, be listened to, make } \\
\text { choices, to say 'no', be } \\
\text { involved in resolving conflict, } \\
\text { choose one's own religion, } \\
\text { participate in decisions and to } \\
\text { have freedom of movement. }\end{array}$ \\
\hline
\end{tabular}

Children's rights per se can never be considered in isolation - to claim a right, or exercise a right, automatically entails a response, or a responsibility, sometimes described as a duty. A significant corollary to children's rights is the notion of citizenship (Heater, 2004; Lister, 2008; May, 2004; Taylor \& Smith, 2009). According to Smith, Bjerke and Taylor (2009), citizenship "involves belonging to and interacting with other people in a group, community or society" (p. 15). How this happens for young children depends on particular 
perceptions of childhood and of children. For example, a common argument against children's rights and notions of children as citizens is implicit within a discourse of children as vulnerable, immature and in need of protection. Further, critics of the idea that children have rights, or agency, argue that perceptions of 'children as citizens' undermine parental authority by privileging the state as a super parent. By contrast, those who advocate the view that children have rights, and can exercise agency, point to the "common sense" understanding that adults have appropriate responsibilities to provide for children, to protect them, and to support their rights to participate in groups, communities and society at large. Rather, as Smith et al., have argued, "agency does not imply autonomous unilateral individuals who lack connections to others in society, but involves a dynamic and reciprocal process of connecting to, and interacting with, other people" (p. 18).

Our position in this paper follows upon Smith et al. (2009): We argue that if we accept the argument that children have citizenship rights just like any other member of society, then it follows that there is a societal obligation to protect those rights. In the context of early childhood education policy, this means that early childhood policy must pay attention to all three categories of rights: children's right to provision of early childhood education, children's right to protection within early childhood services, and children's right to participate in early childhood education. Similarly, if we accept that agency does not mean an individualistic engagement with the world but a reciprocal and dynamic one, then it follows that an early childhood policy that supports children's agency is best conceptualised not as an isolated entity, but rather as part of an integrated system, or supportive policy infrastructure, focused on children as part of the nation's citizenry.

\section{Children's rights as a lens for analysing the policy infrastructure for early childhood services in 2009}

The view that early childhood services should be supported by a comprehensive infrastructure or support system is well established in policy scholarship. For example, the Organisation for Economic Cooperation and Development (OECD, 2001, 2006) advocated a holistic and integrated approach to early childhood policy citing Gallagher and 
Clifford's (2000) work in identifying eight elements as necessary components of such a policy structure:

1. personnel preparation;

2. technical assistance;

3. applied research and programme evaluation;

4. communication;

5. demonstration;

6. data systems;

7. comprehensive planning; and

8. co-ordination of support elements.

Within the New Zealand context, it is possible to argue that a range of policies introduced since the mid-1990s have built up the kind of comprehensive policy structure for early childhood services advocated by the OECD (2001, 2006) and Gallagher and Clifford (2000). For example, Taylor et al. (2009) recently argued that "New Zealand takes children's rights seriously" (p. 83) and cited the following key policy decisions as illustrating support for children as having citizenship rights:

- the appointment of a Children's Commissioner (1989);

- New Zealand's ratification of the UNCRC (1993) (e.g., UNICEF, 2010);

- the Agenda for Children (Ministry of Social Development, 2002); and

- Pathways to the Future: Ngā Huarahi Arataki (Ministry of Education, 2002).

Elsewhere, we too have claimed that there is a history of New Zealand early childhood education policies and other initiatives ${ }^{2}$ that support children's rights (Dalli, 2002; Dalli \& Mitchell, 1995; Dalli \& Te One, 2002; see also May, 2001; Smith, 1996, 2002, 2007a, 2007b). However, while in many cases early childhood policies have complied with the provisions of the UNCRC, their relevance to it has often been assumed rather than articulated (Te One, 2004) and the UNCRC has not been identified overtly as their starting point. Nevertheless many early childhood policies can be held up as examples of how policies support children's provision and participation rights. 


\section{Example 1: Children's provision and participation rights in pedagogical policies}

A key pedagogical policy from the mid-1990s was the introduction of the early childhood curriculum document, Te Whäriki. While the document does not make explicit mention of children's rights, its release in 1996 represented a significant step towards recognising the rights of New Zealand's youngest children to quality early childhood experiences in formally organised early childhood education settings. The following widely-quoted aspiration for children is couched in terms that implicitly advocate for children's rights:

To grow up as competent and confident learners and communicators, healthy in mind, body, and spirit, secure in their sense of belonging and in the knowledge that they make a valued contribution to society. (Ministry of Education, 1996a, p. 9)

Implicit within this aspiration is a view of the child as competent and able to contribute to society as a citizen who also has rights to: health, security, and a sense of belonging. In the process of writing $T e$ Whäriki in the early 1990s Helen May and Margaret Carr asked the question of what makes a good child (Te One, 2003). The curriculum strands of Belonging, Well-being, Exploration, Communication, and Contribution (Ministry of Education, 1996a) were a way of capturing the answer to this question as aspirations for children embedded also in the principles of empowerment, of family and community, of relationships, and of holistic development.

Part of the negotiations for the development of Te Whäriki (Ministry of Education, 1996a) included an undertaking by government to support the development of an assessment framework. Through research undertaken in the late 1990s, a narrative formative assessment tool was developed called Learning Stories based on the principle of identifying children's dispositions and writing narratives about them (Carr, 2001).

As a complementary development, Carr, May and Podmore (2002) also developed questions aimed at each curriculum strand and posed from the child's perspective, thus acknowledging that "children have a voice of their own, and should be listened to as a means of taking them seriously" (Dahlberg, Moss \& Pence, 1999, p. 49; see also Lansdown, 1994; Woodhead, 1999). These five 'child's voice' questions were designed to be a reflective tool for teachers to evaluate their practices (Carr, May \& Podmore, 1998) and to shift the focus 
towards a more rights-based approach. For the strand of Contribution, Carr et al. (2002) suggested the child's voice question of "Is this place fair for me?" (p. 119). From a Children's Rights perspective, this question is central to any discussion about children's rights in early childhood settings: It implies that children have a right to be in a setting, and in a way that enables them to participate and contribute in it fairly - as articulated in Article 12.1 (Child Rights Information Network, 2007, p. 5) of UNCRC. Smith (2007a, 2007b) has argued that both Learning Stories and Teaching Stories support children's rights as stakeholders in their own learning.

Following extensive trialling of the initial learning and teaching stories frameworks, Kei Tua o te Pae Assessment for Learning: Early Childhood Exemplars (Ministry of Education, 2005) was published as a professional resource for teachers. The resource features the child's voice as a contributor to their assessment, alongside teachers' and parents' perspectives, as important influences on curriculum decisions and directions thereby making the focus on children's rights more explicit. A recent report evaluating the implementation of professional development to support Kei Tua o te Pae (KTOTP) (Ministry of Education, 2005) noted the effectiveness of this approach and reported that "assessment documentation did clearly evidence a credit-based approach to assessment in that items reflected the passions, skills and working theories of individual children, and presented them as confident and competent individuals" (Stuart, Aitken, Gould, \& Meade, 2008, p. 9).

The KTOTP resource (Ministry of Education, 2005) is an example of how regulations and practices can cohere to support participation rights for children at the same time that they improve the overall quality of the services provided, hence supporting children's provision rights as citizens. However, the question remains: how do children "contribute" to an early childhood pedagogical setting? How do children assume responsibility? How do they understand justice and fairness? These are questions about power, where it resides and whether or not it is shared; they speak directly to the overall ecology in which children live their early childhood lives. Empowerment is a central concept in UNCRC, especially Article 12 (Child Rights Information Network, 2007), which articulates the child's right to participate in decisions that affect them. Certainly, many official policy documents (Ministry of Education, 1996b, 1998, 2006) include 
principled statements supporting power sharing and emphasising partnerships between teachers and parents; additionally, recent research has extended understandings of partnerships beyond the dyadic teacher-parent relationship to include theoretical ideas about the community as a partner (Ministry of Education, 2002). A logical implication of such a discourse is that as members of the community, children too should be considered active partners and participants in decision making in policy and practice. According to Prout and Hallett (2003), this is "critical to creating institutions (whether statutory, voluntary, private or in the informal sector of family and community) that are responsive and flexible in their work for children" (p. 2). As MacNaughton, Hughes and Smith (2007) have illustrated in two Australian case studies of possible ways that children can participate in early years policy, young children (including some aged two years or younger) can express their views on issues that affect them. MacNaughton et al. concluded that:

listening to young children is the first step to regarding children's rights as rights of citizenship, rather than as rights defined - and restricted - by age...Honouring young children's rights to express their views creates more effective policy ... and contributes to a healthy democracy which recognises that children's rights are the human rights of any citizen. (p. 469)

\section{Example 2: Children's citizenship rights and the Ten-year Strategic Plan for Early Childhood Education: Ngā Huarahi Arataki}

As noted earlier, in New Zealand an explicit aspiration towards citizenship rights ${ }^{3}$ has emerged only recently in arguments about the provision of early education (May, 2005; May \& Mitchell, 2009; Smith, 2009; Smith \& May, 2006). These are generally linked to the implementation of the ten-year Strategic Plan for early childhood education, Nga $\bar{a}$ Huarahi Arataki, introduced in 2002 (Ministry of Education, 2002).

From a child-rights-based perspective, the Strategic Plan has much to commend it as a statement about provision rights, and as a guide for increasing the visibility of children in the social sphere. Its conceptual framework includes three goals: increasing participation; improving the quality of early childhood services; and increasing collaboration in children's services.

From the perspective of the wider ecology of the early childhood educational setting, the Strategic Plan is likewise commendable as it 
laid out a raft of policies to be achieved in steps over a 10-year period which together provide a policy infrastructure of the type advocated by the OECD $(2001,2006)$ and Gallagher and Clifford (2000). The policies include:

- new funding and regulatory systems;

- better support for community-based early childhood services;

- the introduction of professional registration for early childhood teachers;

- better co-operation and collaboration between EC services, parent support and development and education, health and social services; and

- greater involvement by Government in early childhood education, particularly in communities where participation in quality early childhood services is low.

As a consequence of this policy infrastructure, from 2002 the early childhood sector experienced a sustained period of stable, planned progress towards outcomes that support children's right to participation in early childhood services and to high quality early childhood provision. For example, Government's commitment to increasing participation was evidenced by the initiation of 18 pilot Early Childhood Education Parent Support and Development (PSD) projects (Bellett, Sankar \& Teague, 2010), and the Promoting Early Childhood Education Participation Project (Dixon, Widdowson, MeagherLundberg, Airini \& McMurchy-Pilkington, 2007). Additionally, numerous research reports contracted between 2002 and 2009 by the Ministry of Education indicated Government's commitment to enhancing the quality of children's experiences in early childhood services. This included the Centre of Innovation action research programme which, through supporting early childhood teaching teams to work with a research associate to document, investigate and disseminate their practice, created a body of exemplars of good quality practice that other teaching teams could refer to (e.g., Meade, 2007, 2010). By bringing teachers together with researchers, the action research programme was also an example of the type of collaboration envisaged in the strategic plan as a potentially very powerful strategy to unite different stakeholders in working for children. 
Also powerful were the stepped targets to incrementally increase the numbers of qualified and registered teachers to $100 \%$ by $2012^{4}$ as a measure to improve the quality of early childhood services provided to children and families. To assist in achieving these targets, a range of incentives was put in place including:

- scholarships to support the attainment of qualifications;

- higher funding rates for services with more registered teachers;

- loan support for students;

- national and international re-location grants.

In Gallagher and Clifford's (2000) model of a supportive policy infrastructure for early childhood services, these incentives would qualify as the first and second components of personnel preparation and technical assistance, while a comprehensive programme of research and evaluation of strategic plan policies throughout its implementation (e.g., Mitchell \& Hodgen, 2008) could be described as Gallagher and Clifford's third component of applied research and program evaluation. Other initiatives funded as part of the Strategic Plan policies conform to the remaining components of Gallagher and Clifford's model as follows:

- practitioner networks established through professional development contracts, and the appointment of co-ordinators to provide advice and support for new services, ensured there was widespread communication (fourth component) across the sector both of strategic plan initiatives and of the support strategies to implement the policies;

- the Centre of Innovation action research programme ensured that there was demonstration (fifth component) of good practice beyond the individual early childhood setting;

- statistical returns collected from all licensed services on 1 July of each year as an established part of Ministry of Education operations provided data systems for early childhood services (sixth component).

In a recent evaluation of the implementation of the first phase of the ten-year Strategic Plan for ECE, Mitchell and Hodgen (2008) pointed out that some populations were still disadvantaged in their ability to access and participate in early childhood services but that the 
Strategic Plan had positively affected children's learning outcomes. The latter findings were linked to increased teacher understanding of Te Whäriki (Ministry of Education, 1996a), improved teacher qualifications, and ongoing funding for professional development supported by the release of professional resources, in particular KTOTP (Ministry of Education, 2005). Thus in their entirety, the Strategic Plan policies illustrate how, as Gallagher and Clifford (2000) argued, through comprehensive planning, it is possible "to allocate resources over time and in a systematic manner to more easily reach the goals of the program" (p. 7). Furthermore, they illustrate that from a Children's Rights perspective, the Strategic Plan policies can be seen as a holistic approach to ensuring that provision and participation rights to high quality early childhood education are accorded to young children as members of society who hold citizenship rights in common with the rest of society. As the noted political commentator Colin James wrote in citing early childhood policy as the most lasting contribution of the Labour-led government's fifth term in office:

Making early childhood systematic...takes us deep into a zone of policy debate: on citizens' access to participation in our economy and society. This debate is ... about what constitutes genuine capacity to participate....so early childhood education is investing in infrastructure, just like building roads. (James, 2008).

\section{The status of early childhood policy in 2009}

2009 was the first full year in office of the National-led centre-right government elected in November 2008. The new government took office just as the effects of the global recession started to be felt in New Zealand with the Treasury's December 2008 economic update predicting a "downside scenario" of a shrinking economy for the following two years (New Zealand Treasury, 2008). The new government swiftly took on a discourse of fiscal responsibility and issued instructions for a line-by-line review of expenditure in all government departments. The first aim of the fiscal review was to identify expenditure that did not line up with government priorities to help free up savings for Budget 2009 (Ministry of Education, 2009b).

For the early childhood education sector, with four of the ten years of the strategic plan still to unfold, the changed political and economic contexts immediately revealed the vulnerability of children's entitlement to high quality early childhood education as a right of citizenship. 
Historically, National governments have opted for a free-market approach to early childhood policy, and their policies have treated early childhood services as a private good rather than a state responsibility (e.g., May, 2001). This stance was evident in a preelection speech at the annual conference of the NZ Childcare Association ${ }^{5}$ in July 2008, by National's then education spokesperson, Paula Bennett. The speech confirmed that a National government would distance itself from hands-on involvement because "parents not the State - have the primary responsibility for the upbringing and development of their children" and because National believed that early childhood education "should back parents - not be a substitute for parents who do not have the means, time or wherewithal for their children" (Bennett, 2008). Bennett also said that a National government would relieve "burdensome" and "needless regulations" and that the requirement for $100 \%$ qualified teachers to work with under-two year olds would be reduced to a requirement for $50 \%$ qualified because: "National believes that some of those looking after our babies do not need a teaching qualification" (Bennett, p. 3).

Immediately following the 2008 general elections and throughout 2009, these early messages about National's preferred approach to early childhood policy were speedily followed with changes to the previous government's ten-year policy strategy. Within days of taking office, it was clear that National's pre-election stance was to be vigorously followed: A review of the newly-amended early childhood regulations was initiated just as they were about to be implemented on 1 December 2008. The result was a softening of licensing requirements in relation to sleeping arrangements and plumbing in early childhood centres. Perpetual licences were also introduced contrary to parental submissions made as part the review process (Ministry of Education, 2009a) - and the minimum age for homebased educators was reduced to the school leaving age of 17 years with "some early childhood training" being the only stipulated training requirement.

Aided by options presented by the Ministry of Education in its Briefing to the Incoming Government (Ministry of Education, 2008), and recommendations made as a result of the line-by-line review of government department expenditure (Ministry of Education, 2009b), the 2009 Budget decisions revealed that many of the Strategic Plan policies to tighten quality standards were in danger of being de-railed, 
and that children's citizenship rights to high quality early childhood education were in question, even while a focus on increasing participation remained part of the policy discourse. The provisions of the 2009 Budget, released on 28 May, were as follows:

- changing the '20 free hours' policy into the '20 hours ECE' policy and extending it to cover three- and four-year-olds attending licensed parent- or whānau-led services, not just teacher-led ones;

- confirmation of a ministerial announcement in January 2009 that planned adult-child ratio improvements (from a minimum of 1:5 to a minimum of 1:4) in group early childhood settings for under-twoyear-olds would not go ahead;

- all ongoing professional development projects were to cease at their completion date in December 2009, with new contracts to be issued in 2010 at a $25 \%$ lower level than in 2009; and

- the Centre of Innovation action research programme was terminated with immediate effect.

Of these provisions, only the extended ' 20 hours ECE' policy was welcomed by the early childhood sector as a move that would support increased participation in high quality early childhood education. It was also the only provision in the 2009 Budget that was accompanied by new resources, justified on the basis that it would "support parent choice and recognise the quality of different types of ECE, by including services and children who were previously unable to access the scheme" (Ministry of Education, 2009c).

The lack of progress on improving adult-child ratios in early childhood settings for under-two-year-olds, on the other hand, was particularly disappointing as the research evidence on the importance of this factor for high quality ECE provision for this age-group is substantial and long-established (e.g., Expert Advisory Panel on Quality Early Childhood Education and Child Care, 2009; Gevers Deynoot-Schaub \& Riksen-Walraven, 2008; Muenchow \& Marsland, 2007; Munton et al., 2002). Although Minister Tolley (2009) later softened the impact of this decision by stating, at the New Zealand Kindergarten Federation Conference in August, that the ratio improvements would be "phased in over the next few years", concern remained that this delay would be detrimental to the quality of early 
childhood education experienced by the growing population of undertwo-year-old children in group-based early childhood services.

Equally disappointing were the two decisions to withdraw funding from ongoing professional development programmes to support teachers in implementing the early childhood curriculum and related assessment practices, and to terminate the Centre of Innovation action research projects. This unexpected wholesale removal of professional development and research support took the sector by surprise and raised fears about the ability of the sector to maintain its momentum towards enhancing quality outcomes for children.

Further concern arose in August when, at the same time as commenting on Government's continued commitment to improving ratios in under-two settings in the long term, the Minister announced (Tolley, 2009) that she had instructed the Ministry of Education to work out options for reducing the target of $100 \%$ qualified teachers working with under-two-year-olds down to $50 \%$, to explore strategies for enabling overseas-qualified teachers to work in early childhood services, and to translate primary teaching qualifications for work in early childhood settings. To a sector which (i) since 1996 had worked with a curriculum document that explicitly stated that the curriculum for infants and toddlers is "specialised" and "neither a scaled-down three- or four-year-old programme nor a baby-sitting arrangement" (Ministry of Education, 1996a, p. 22), and (ii) since 1988 had been on a trajectory of rationalising pre-service qualifications for early childhood teaching, including through the introduction of three-year diplomas or degrees as the benchmark qualification, these announcements seemed anachronistic and regressive. The additional announcement in October that the government was aiming to attain an $80 \%$ (vs $100 \%$ ) qualified early childhood workforce by 2012 , and that the Strategic Plan policy of 100\% qualified teachers by 2012 was no longer part of the government's plan for early childhood education, turned concern into alarm (New Zealand Childcare Association, 2009). It became clear that the sector was facing significantly different policy conditions and a new set of priorities in which the coherent infrastructure of the ten-year strategic plan was in danger of being dismantled.

From a children's rights perspective, the gradual but persistent unpacking of the integrated infrastructure of the ten-year strategic plan during 2009 is significant: It illustrates the ease with which children's 
citizenship rights to high quality early childhood education provision are able to be overlooked, including through the discourse of parents having the primary responsibility for their children, not the state (Bennett, 2008), and the discourse of economic imperatives. For example, the Briefing to the Incoming Minister (Ministry of Education, 2008) stated that "the fiscal costs of early childhood education are expected to rise above inflation over the next three years as a result of current policy, increased demand and growth of the ECE sector" (p. 15). Consequently, the Briefing noted that:

Government may wish to reconsider the balance of universal and targeted subsidies and assistance to effectively meet these challenges. Increasing supply, especially in areas where there are high numbers of Māori and Pasifika children, high population growth and socio-economic disadvantage, has the potential to produce the greatest gains. (p. 15)

This advice to the incoming government clearly pits targeted subsidies against universal provision as a recommended policy option. In so doing, it implicitly disregards the option of a principled commitment to universal provision on the grounds that this is a right that accrues to children from their status as citizens. In subsequently elaborating the various options government could use to "assist the development of early childhood education in areas of high need" (p. 16), the briefing added:

the key point is that increased assistance to the children that could benefit most from high-quality early childhood education services will need to be at the expense of more general assistance for all families. The alternative is further growth in the overall fiscal cost of ECE services. (p. 16)

Thus, while advancing a discourse of increased participation, early childhood policy in 2009 also leaned heavily on a discourse of fiscal constraints. It emphasised parental rights over state responsibility, and targeted assistance above universal funding. This signalled debates that are likely to continue to occupy the sector in years to come.

\section{Towards a new rights-based critical ecology of the early childhood sector}

In a paper that analysed recent trends in the professionalising of the New Zealand early workforce as the outcome of a history of sector advocacy and strategy, one of us (Dalli, 2010) argued that this history illustrates a critical ecology within the early childhood profession. Reviewing the current policy context, with its emphasis on economic constraints, Dalli called for the emergence of a new critical ecology 
that responds to the current context. In this final section we argue that the new critical ecology needs to be one in which children's rights to high quality early childhood education services are taken seriously.

The term "critical ecology of the profession" refers to the idea that within a profession that is critical of its ecology, members are reflective, self-critical and alert to the "challenges within [the profession's] settings and to the strengths that can be brought to bear to make the present better" (Dalli, 2007, 2010, p. 70). Within such a profession there is "a critical dimension of thinking about current and possible future policies and practices" (Urban, 2008, p. 146). This includes the ability to engage critically with the ideological and philosophical positionings that various stakeholders within a professional field might take, such that possible futures can be envisioned that move beyond the limitations of the present.

Such a stance has clear implications for the children's rights perspective applied in reviewing early childhood education policy in this paper. For example, having an early childhood profession that is critical of its ecology would mean that the challenges arising from the changed policy context of 2009 would give rise to vigorous debates within the sector, including about:

- what it might mean to target resources at disadvantaged or 'at-risk' populations in terms of government's ideological stance vis-à-vis the right of all children to participate in quality early childhood education. What role is government staking as its own when targeted resourcing is the chosen strategy over universal provision? How does this impact the availability of early childhood services to children and their families more globally? What impact will it have on the marketisation of early childhood education? What do such policy options mean in relation to the role of early childhood teachers within a mixed economy of the early childhood education?

- the likely impact of the lack of improvements in adult-child ratios in group early childhood education settings for under-two-yearolds. What might this mean for the way that very young children experience their childhood? Can adults working under these conditions provide the type of attuned intersubjective interactions that research (e.g., Jaffee, 2007; Jaffe, Beebe, Feldstein, Crown \& Jasnow, 2001; Rommetveit, 1998; Warner, 2002) has identified as necessary for optimal development and learning for this age-group? 
- the effect of limiting the proportion of qualified adults working with under-twos to $50 \%$, and with older children to $80 \%$, rather than $100 \%$ for all age-groups. How will teachers' pedagogical environment be affected by working alongside untrained staff who will no longer be expected to achieve full qualifications? What will be the combined effect of reducing the qualifications requirements, and reducing government investment in universal provision on the overall quality of early childhood services in a mixed economy context? How will pedagogical imperatives be weighed up against fiscal ones in early childhood settings driven by a profit motive?

Signs of the emergence of such a critical ecology were beginning to be visible in the latter part of 2009, including in a spirited campaign to re-instate the Centre of Innovation action research programme which was terminated as part of the Budget process, and in press releases issued by early childhood advocacy groups after the announcement of the reduced qualifications targets (e.g., New Zealand Childcare Association, 2009).

Notable among the emerging critical responses was the release in November 2009 of the report on the Quality Public Early Childhood Education Project (QPECE) (May \& Mitchell, 2009). Utilising "the right to education framework adopted by the NZ Human Rights Commission from the UN Economic and Social Council (1999)" (p. 11), the report asserted young children's citizenship rights to early childhood education and envisaged a time when it would be taken for granted that "every child has a right as a citizen to participate in free education; [and when] every family that wishes to, can access high quality, community-based early childhood education" (May \& Mitchell, p. 4). With international models of ECE provision as a comparison, May and Mitchell evaluated the current state of ECE provision in New Zealand under the headings of availability, accessibility, acceptability, and adaptability of early childhood services. The result is a critique that highlights both the positive impacts of policy, as well as existing barriers to the achievements of the three goals of QPECE for 2020:

1. Promotion of community-based ECE services including whānau/parent-led services through the development of a national plan for all ECE provision throughout Aotearoa New Zealand. 
2. Provision of appropriate services to ensure every child can participate in free, high quality ECE.

3. Robust accountability to Government, parents, whānau and communities, linked to indicators that demonstrate high quality ECE. (May \& Mitchell, 2009, p. 4)

May and Mitchell (2009) concluded that ECE is "a right of all children, an entitlement and a public responsibility that should be offered free of charge" (p. 18). They envisage an early childhood context in which new collaborative partnerships exist at national and local levels to create "coherent patterns of ECE provision ... not only strengthening children's learning and wellbeing, but also ... supporting adults and building community cohesion" (p. 19).

The QPECE report (May \& Mitchell, 2009) presents a bold picture of what a future early childhood education sector might look like when founded on a rights-based framework that accords children the same rights of citizenship that adults have. It is a picture that is in line with international research on children's rights, including their rights to high quality early childhood education, and children's rights within early childhood services. This research indicates a move towards educating children as citizens in a democracy (Dahlberg \& Moss, 2005; Howe \& Covell, 2000; Kehily, 2004; Lindahl, 2005; MacNaughton, et al., 2007; May, 2005; Taylor \& Smith, 2009). We suggest that to consider the New Zealand context from this perspective raises the question of whether we are indeed a democracy that takes children's rights seriously.

\section{Conclusion}

In this paper we have argued that if we accept the provision, protection and participation rights of children articulated in the UNCRC, then it follows that governments have a responsibility to provide early childhood education services of a high quality for children and their families. A government's role in providing educational services is executed via policies and regulations that are subsequently implemented by educators. We have argued that in recent years the New Zealand early childhood education sector has operated within an overall policy context that implicitly adhered to the provisions of UNCRC, including in the comprehensive policy 
infrastructure of the ten-year early childhood strategic plan, $N g \bar{a}$ Huarahi Arataki (Ministry of Education, 2002). However, policy decisions during 2009, justified through a discourse of economic constraints, have de-railed somewhat the smooth trajectory of the implementation of these strategic plan policies and raised questions about the government's ideological stance towards the right of all children to participate in quality early childhood education. We note also that further budget cuts are projected over the 2010-2012 period (see Te One, 2010) signalling the likelihood of future changes that might put the quality of early childhood services available to children and families at further risk.

As we conclude this paper we reflect that the current government has not openly rejected the overall aspirations of the 10-year early childhood education strategic plan, nor has it explicitly resiled its responsibility to adhere to UNCRC, on which it was due to report in 2010. Indeed, government's discourse of increasing participation in high-quality early childhood education remains firm. Nonetheless, significant policies that provide the wider framework within which children experience their early childhood setting (e.g., required teacher qualifications; the availability of professional development opportunities) have been removed. We have argued that the cost cutting achieved by the removal of this support potentially damages progress towards achieving the aspiration of a better early childhood education for New Zealand children, to which children have citizenship rights. We have also argued that a new critical ecology is needed within the sector that highlights these rights; there are signs that such a critical stance is emerging.

\section{References}

Bellett, D., Sankar, M., \& Teague, M. (2010). Early childhood education centred-based parent support and development: Final Report. http://www.educationcounts.govt.nz/publications/ece/74648

Bennett, P. (2008/July). Speech at the NZCA annual conference in Christchurch. http://www.nzca.ac.nz/nationalpartyECEpolicy

Carr, M., May, H., \& Podmore, V. N. (1998). Learning and teaching stories: New approaches to assessment and evaluation in relation to Te Whariki. Wellington: Institute for Early Childhood Studies.

Carr, M. (2001). Assessment in early childhood settings: Learning stories. London: Paul Chapman. 
Carr, M., May, H., \& Podmore, V. (2002). Learning and teaching stories: Action research on evaluation in early childhood in Aotearoa-New Zealand. European Early Childhood Research Journal, 10(2), 115-126.

Child Rights Information Network. (2007). Convention on the rights of the child [Electronic Version]. Children's rights information network, 1-22. Retrieved June 25, 2007 from http://www.crin.org/docs/resources/treaties/ uncrc.asp

Dahlberg, G., \& Moss, P. (2005). Ethics and politics in early childhood education. London: RoutledgeFalmer.

Dahlberg, G., Moss, P., \& Pence, A. (1999). Beyond quality in early childhood education and care: Postmodern perspectives. London: Falmer Press.

Dalli, C. (2002). Early childhood policy in New Zealand: Stories of sector collaborative action in the 1990s. Paper presented to the Country Seminar for Education International, Wellington, New Zealand.

Dalli, C. (2007, September) Towards a critical ecology of the profession: Systematic approaches to policies, practices, and understandings of professionalism and professionalisation in EC. Symposium paper presented at the European EC Education Research Association Annual Conference, Prague, Czech Republic.

Dalli, C. (2010). Towards the re-emergence of a critical ecology of the early childhood profession in New Zealand. Contemporary Issues in Early Childhood, 11(1), 61-74.

Dalli, C., \& Mitchell, L. (1995) The Early Childhood Code of Ethics or How you can prise yourself from between a rock and a hard place. Keynote address, Proceedings of the 6th Early Childhood Convention, Auckland 5-8 September 1995, Vol 1, pp. 63-76.

Dalli, C., \& Te One, S. (2002). Early childhood education in 2002: Pathways to the future. In I. Livingston (Ed.), New Zealand Annual Review of Education, $12,177-202$.

Dixon, R., Widdowson, D., Meagher-Lundberg, P. Airini \& McMurchy-Pilkington, C. (2007). Evaluation of promoting early childhood education (ECE) Participation Project. http://www.educationcounts.govt.nz/publications/ece/ $\underline{11760}$

Expert Advisory Panel on Quality Early Childhood Education and Child Care. (2009). Towards a national quality framework for early childhood education and care: Report of the expert advisory panel on quality early childhood education and care. Canberra, Australia: DEEWR.

Gallagher, J., \& Clifford, R. (2000). The missing support infrastructure in early childhood. Early Childhood Research and Practice, Spring, 2000. Retrieved, March, 4, 2008, from http://ecrp.uiuc.edu/v2n1/gallagher.html 
Gevers Deynoot-Schaub, J., \& Riksen-Walraven, J. M. (2008). Infants in group care: Their interactions with professional caregivers and parents across the second year of life. Infant Behavior \& Development, 31(2), 181-189.

Heater, D. B. (2004). Citizenship: The civic ideal in world history, politics and education (3rd ed.). Manchester: Manchester University Press.

Howe, B., \& Covell, K. (2005). Empowering children: Children's rights education as a pathway to citizenship. Toronto: Toronto University of Toronto Press.

Jaffe, J., Beebe, B., Feldstein, S., Crown, C. L., \& Jasnow, M. D. (2001). Rhythms of dialogue in infancy. Monographs of the Society for Research in Child Development, 66(2).

Jaffee, S. R. (2007). Sensitive, stimulating caregiving predicts cognitive and behavioural resilience in neurodevelopmentally at-risk infants. Development and Psychopathology, 19, 631-647.

James, C. (2008). Educating under-5s: Perhaps Labour's biggest idea, NZ Herald, 19 February 2008. http://www.colinjames.co.nz/herald/Herald_2008/Herald_ column_08Feb19.htm

Kehily, M. J. (Ed.). (2004). An introduction to childhood studies. Maidenhead: Open University Press.

Lansdown, G. (1994). Children's rights. In B. Mayall (Ed.), Children's childhoods: Observed and experienced (pp. 33-44). London: Falmer Press.

Lindahl, M. (2005). Children's right to democratic upbringings. International Journal of Early Childhood, 37(3), 33-47.

Lister, R. (2008). Unpacking children's citizenship. In A. Invernizzi \& J. Williams (Eds.), Children's citizenship (pp. 9-20). London: Sage.

MacNaughton, G., Hughes, P., \& Smith, K. (2007). Young children's rights and public policy: Practices and possibilities for citizenship in the early years. Children and Society, 21, 458-469.

May, H. (2001). Politics in the playground: The world of early childhood in postwar New Zealand. Wellington, NZ: Bridget Williams Books.

May, H. (2004). Towards citizenry rights in the early childhood sector 1930s2000s. Paper presented at the European Early Childhood Education Research Association Conference, Malta.

May, H. (2005). A right as a citizen to a free [early childhood] education 1930s2000s. Childrenz Issues, Journal of the Children's Issues Centre, 9(2), 20-24.

May, H., \& Mitchell, L. (2009). Strengthening community-based early childhood education in Aotearoa New Zealand: Report of the Quality Public Early Childhood Education Project. Wellington: NZEI Te Riu Roa. New Zealand Educational Institute. 
Meade, A. (Ed.). (2007). Cresting the waves: Innovation in early childhood education. Wellington: NZCER Press.

Meade, A. (Ed.). (2010). Dispersing waves: Innovation in early childhood education. Wellington: NZCER Press.

Ministry of Education. (1996a). Te Whariki. He whariki matauranga mo nga mokopuna o Aotearoa: Early childhood curriculum. Wellington: Learning Media.

Ministry of Education. (1996b). Revised statement of desirable objectives and practices (DOPS) for chartered early childhood services in New Zealand. The New Zealand Gazette, 3 October.

Ministry of Education. (1998). Quality in action: Te mahi whai hua. Implementing the revised statement of desirable objectives and practices in New Zealand early childhood services. Wellington: Learning Media.

Ministry of Education. (2002). Pathways to the future: Ngā huarahi arataki: A 10 year strategic plan for early childhood education. Wellington: Ministry of Education.

Ministry of Education. (2005). Kei tua o te pae assessment for learning: Early childhood exemplars. Wellington, NZ: Learning Media.

Ministry of Education. (2006). Nga arohaehae whai hua. Self-review guidelines for early childhood education. Wellington, NZ: Learning Media.

Ministry of Education. (2007). Early childhood policy [Electronic Version]. Social Policy Journal of New Zealand. Retrieved March 20, 2009, from http://www.msd.govt.nz/about-msd-and-our-work/publications-resources/ journals-and-magazines/social-policy-journal/spj32/32-early-childhoodeducation-policy-pages88-93.html\#ParentSupportandDevelopment4.

Ministry of Education. (2008). Briefing to the incoming minister. November 2008. http://www.beehive.govt.nz/sites/all/files/MinEdu_BIM.pdf

Ministry of Education. (2009a). Early childhood education 2008 Regulations review. Summary report for consultation for sector working group. http://www.lead.ece.govt.nz/ManagementInformation/Regulatory

FrameworkForECEServices/ /media/Educate/Files/Reference\%20Downloads/Le ad/Files/SummaryConsultationWorkingGroup.ashx

Ministry of Education. (2009b). Vote Education: 2009 Budget line by line review. http://www.minedu.govt.nz/ /media/MinEdu/Files/TheMinistry/budget2009/ 09VoteEducation2009BudgetLineByLineReview.pdf

Ministry of Education. (2009c). Budget 2009 education initiatives. http://www.minedu.govt.nz/theMinistry/Budget/Budget2009/EducationInitiati ves.aspx\#EarlyChildhoodEducation 
Ministry of Social Development. (2002). New Zealand's agenda for children: Making life better for children. Wellington, New Zealand: Ministry of Social Development.

Ministry of Social Development. (2006). Early years service hubs. Unpublished Background paper, Ministry of Social Development.

Ministry of Social Development \& Ministry of Education. (2004). ECE centre based parent support. Overview paper.

Mitchell, L., \& Hodgen, E. (2008). Locality-based evaluation of Pathways to the Future: Ngā Huarahi Arataki - Stage 1 Report. http://www.educationcounts. govt.nz/publications/ece/28948/28949

Muenchow, S., \& Marsland, K. W. (2007). Beyond baby steps: Promoting the growth and development of U.S. child-care policy. In J. L. Aber (Ed.), Child development and social policy: Knowledge for action. APA Decade of Behavior volumes (pp. 97-112). Washington, DC, American Psychological Association.

Munton, T., Mooney, A., Moss, P., Petrie, P. Clark, A., \& Woolner, J. (2002). Research on ratios, group size and staff qualifications and training in early years and childcare settings. (Research Report No.320). London: Thomas Coram Research Unit, Institute of Education, University of London.

New Zealand Childcare Association. (2009). Govt urged to maintain momentum on ECE qualification targets. Available at: http://www.nzchildcare.ac.nz/news/ 2009/Govt-urged-to-maintain-momentum-on-ECE-qualification-targets

New Zealand Treasury. (2008). Economic and fiscal forecasts, December 2008. http://www.treasury.govt.nz/budget/forecasts/eff2008/13.htm

OECD. (2001). Starting strong: Early childhood education and care. Paris. OECD.

OECD. (2006). Starting strong 11: Early childhood education and care. Paris. OECD.

Podmore, V. N., Meade, A., \& Kerslake Hendricks, A. (2000). Aspects of quality in early education. Wellington, NZ: New Zealand Council of Educational Research.

Prout, A., \& Hallett, C. (2003). Introduction. In C. Hallett \& A. Prout (Eds.), Hearing the voices of children: Social policy for a new century (pp. 1-8). London: RoutledgeFalmer.

Rommetveit, R. (1998). Intersubjective attunement and linguistically mediated meaning in discourse. In S. Braten (Ed.), Intersubjective communication and emotion in early ontogeny (pp. 354-375). Cambridge: Cambridge University Press. 
Smith, A. B. (Ed.). (1996). The quality of childcare centres for infants in New Zealand. Palmerston North: The New Zealand Association for Research in Education/Department of Policy Studies, Massey University.

Smith, A. B. (2002). Interpreting and supporting participation rights: Contributions from sociocultural theory. The International Journal of Children's Rights, 10, 73-88.

Smith, A. B. (2007a). Children's rights and early childhood education: links to theory and advocacy. Australian Journal of Early Childhood, 32(3), 1-8.

Smith, A. B. (2007b). Children and young people's participation rights in education. International Journal of Children's Rights, 15, 147-164.

Smith, A. B. (2009, November). Implementing the UNCRC in New Zealand: How are we doing in early childhood? Paper presented at the NZARE, ECE Special Interest Group, NZARE Annual Conference, Rotorua.

Smith, A. B., \& May, H. (2006). Early childhood care and education in Aotearoa-New Zealand. In E. Melhuish (Ed.), Preschool care and education: International perspectives (pp. 144-176). London: Routledge.

Smith, A. B., Bjerke, H., \& Taylor, N. J. (2009). The meaning of citizenship for children [Electronic Version]. Childrenz Issues: Journal of the Children's Issues Centre, 13, 43-49, 55, 63. Retrieved Aug 21, 2010, from $<$ http://search.informit.com.au/documentSummary;dn=797615321207137;res $=$ IELHSS $>$.

Stuart, D., Aitken, H., Gould, K., \& Meade, A. (2008). Evaluation of the implementation of Kei Tua o te Pae Assessment for Learning: Early childhood exemplars: Impact evaluation of the Kei Tua o te Pae 2006 professional development. http://www.educationcounts. govt.nz/publications/ece/26255/ 26256

Taylor, N. J., \& Smith, A. B. (Eds.). (2009). Children as citizens? International voices: Childwatch International, Citizenship Study Group. Dunedin, N.Z: Otago University Press.

Taylor, N. J., Smith, A. B., \& Gollop, M. (2009). Children's perspectives on rights, responsibilities and citizenship: New Zealand. In N. J. Taylor \& A. B. Smith (Eds.), Children as citizens? International voices (pp. 81-98). Dunedin: University of Otago Press.

Te One, S. (2003). Te Whāriki: Contemporary issues of influence. In J. Nuttall (Ed.), Weaving Te Whāriki: Aotearoa New Zealand's early childhood curriculum document in theory and in practice (pp. 17-49). Wellington: New Zealand Council for Educational Research Press.

Te One, S. (2004). Children's rights and early childhood policy: Impacts and influences. New Zealand Annual Review of Education, 14, 171-193. 
Te One, S. (2010). Early childhood education: New pathways to an uncertain future. Working Paper published as supporting paper for the ACYA report to the United Nations Committee on the Rights of the Child. In Children and Youth in Aotearoa 2010: Action for Children and Youth Aotearoa.

Tolley, A. (2009). Speech to the New Zealand Federation Conference, Wellington, Michael Fowler Centre, 8 August.

UNICEF. (2010) Local government: Respecting the rights of our children. Retrieved from: http://www.unicef.org.nz/store/doc/Respecting-Rightsreport.pdf

United Nations. (1990). Convention on the Rights of the Child. http://www2.ohchr.org/english/law/crc.htm

Urban, M. (2008). Dealing with uncertainties: Challenges and possibilities for the early childhood profession. European Early Childhood Education Research Journal, 16(2), 135-152.

Warner, R. M. (2002). Rhythms of dialogue in infancy: Comments on Jaffe, Beebe, Feldstein, Crown, \& Jasnow (2001). Journal of Psycholinguistic Research, 31(4), 409-420.

Woodhead, M. (1999). Towards a global paradigm for research in early childhood education. European Early Childhood Education Research Journal, 7(1), 5-22.

\section{The authors}

Sarah Te One is a lecturer at Victoria University of Wellington where she is currently teaching childhood sociology, children's rights and researching parent support and development in early childhood services. She has been involved in several major research projects including Centres of Innovation and a TLRI. Sarah's interests are in children's rights in early childhood education, policy, and research.

Email: sarah.teone@vuw.ac.nz

Carmen Dalli is an associate professor at Victoria University of Wellington, director of the Institute for Early Childhood Studies and associate director of the Jessie Hetherington Centre for Educational Research. Her research interests and publications span the areas of development in the early years, professionalism and ethical practice, and early childhood policy.

Email: carmen.dalli@vuw.ac.nz

Sometimes also referred to as UNCROC 
2 The New Zealand Early Childhood Code of Ethics is framed around a language of rights (See Dalli \& Mitchell, 1995)

3 Children's rights, and indeed human rights, are not necessarily the same as citizenship or citizenry rights. For example, children's citizenship rights raise issues about who is excluded from attending and participating in early childhood provisions. Thus, the notion of citizenship actually narrows the concept of universal rights to those rights that flow from membership of a political entity - the state. In the case of New Zealand, this is evident in the reservation it has against UNCRC which acts to exclude refugee children, and children of illegal immigrants from access to public services such as health and education. This example highlights that the moral obligations of a State, such as those expressed in UNCRC, are not as easily measured as the legal ones.

4 The interim targets were: (i) by 2005 all 'persons responsible' in a licensed centre to be registered as teachers through the New Zealand Teachers Council (ii) by $2007,50 \%$ of all regulated staffing to be registered teachers; (iii) by 2010 , the percentage of registered teachers to rise to $80 \%$.

5 The full name of the association is Te Tari Puna Ora o Aotearoa- New Zealand Childcare Association. 